\title{
Increasing the Protein Content of Ice Cream ${ }^{1}$
}

\author{
M. R. Patel, ${ }^{2}$ R. J. Baer, ${ }^{3}$ and M. R. Acharya ${ }^{4}$ \\ Dairy Science Department, South Dakota State University, Brookings 57007-0647
}

\begin{abstract}
Vanilla ice cream was made with a mix composition of $10.5 \%$ milk fat, $10.5 \%$ milk SNF, $12 \%$ beet sugar, and $4 \%$ corn syrup solids. None of the batches made contained stabilizer or emulsifier. The control (treatment 1) contained $3.78 \%$ protein. Treatments 2 and 5 contained $30 \%$ more protein, treatments 3 and 6 contained $60 \%$ more protein, and treatments 4 and 7 contained $90 \%$ more protein compared with treatment 1 by addition of whey protein concentrate or milk protein concentrate powders, respectively. In all treatments, levels of milk fat, milk SNF, beet sugar, and corn syrup solids were kept constant at $37 \%$ total solids. Mix protein content for treatment 1 was $3.78 \%$, treatment 2 was $4.90 \%$, treatment 5 was $4.91 \%$, treatments 3 and 6 were $6.05 \%$, and treatments 4 and 7 were $7.18 \%$. This represented a $29.89,60.05,89.95,29.63,60.05$, and $89.95 \%$ increase in protein for treatment 2 through treatment 7 compared with treatment 1 , respectively. Milk protein level influenced ice crystal size; with increased protein, the ice crystal size was favorably reduced in treatments 2,4 , and 5 and was similar in treatments 3,6 , and 7 compared with treatment 1 . At $1 \mathrm{wk}$ postmanufacture, overall texture acceptance for all treatments was more desirable compared with treatment 1 . When evaluating all parameters, treatment 2 with added whey protein concentrate and treatments 5 and 6 with added milk protein concentrate were similar or improved compared with treatment 1 . It is possible to produce acceptable ice cream with higher levels of protein.
\end{abstract}

Key words: ice cream, protein, milk protein concentrate, whey protein concentrate

\footnotetext{
Received November 2, 2005.

Accepted November 23, 2005.

${ }^{1}$ Published with the approval of the South Dakota Agricultural Experiment Station as Publication Number 3529 of the Journal Series. This research was sponsored in part by Wells' Dairy Inc., LeMars, IA.

${ }^{2}$ Current address: Kemps LLC, 406 North Broadway, P.O. Box 309, Rochester, MN 55903-0309.

${ }^{3}$ Corresponding author: robert.baer@sdstate.edu

${ }^{4}$ Current address: Wells' Dairy, Inc., One First Street S. W., LeMars, IA 51031.
}

\section{INTRODUCTION}

Both whey protein concentrate (WPC) and milk protein concentrate (MPC) are excellent sources of high quality protein. Whey protein concentrates are products derived from whey, the residual liquid substance that is obtained by separating the coagulum from milk during cheese making. Whey proteins are concentrated by removal of minerals and lactose from whey through UF, electrodialysis, ion exchange, or crystallization of lactose (Chandan, 1997). Whey protein concentrate addition to frozen desserts produces favorable sensory and textural qualities (Huse et al., 1984; Parsons et al., 1985; Opdahl and Baer, 1991; Hofi et al., 1993; Tirumalesha and Jayaprakasha, 1998; Koxholt et al., 1999). Whey protein concentrate is included in ice cream at the expense of NDM (Dunker, 1984) and it has the added benefit of being nutritionally superior to NDM, which gives it an advantage from a formulation standpoint (Dahm, 2000).

Milk protein concentrate is produced by UF and diafiltration of milk, followed by a 2 -stage drying process of evaporation and spray drying. Milk protein concentrate formulations were found to have higher ice cream mix viscosity, narrower ice melting curves, and greater shape retention in ice cream (Alvarez et al., 2005). No textural improvements in iciness development were apparent from use of MPC in place of NDM, and the small differences in physical properties suggest that MPC could be incorporated to produce a suitable ice cream. Milk protein concentrates, when substituted for up to $50 \%$ of the protein supplied by NDM, did not offer significant modifications of ice cream physical properties on a constant protein basis. Sensory iciness scores after $60 \mathrm{~d}$ of storage suggested that any differences between MPC and control mixes in textural quality were small and not observable. Iciness sensory scores for the MPC and control heat-shocked ice creams were similar. Milk protein concentrate could be incorporated to produce a suitable ice cream, which may be important when considering alternate sources of milk SNF to replace NDM for production of lactose- or fat-reduced ice cream.

It is hypothesized that ice cream higher in protein can be produced by adding WPC or MPC. Whey protein concentrates or MPC could be used by ice cream manufacturers to produce acceptable quality ice cream that 
Table 1. Ice cream mix treatments

\begin{tabular}{|c|c|c|c|c|c|c|}
\hline \multirow[b]{2}{*}{ Treatment $^{2}$} & \multicolumn{3}{|c|}{$\mathrm{WPC}^{1}(\%)$} & \multicolumn{3}{|c|}{$\operatorname{MPC}^{1}(\%)$} \\
\hline & 30 & 60 & 90 & 30 & 60 & 90 \\
\hline \multicolumn{7}{|l|}{$\mathrm{T} 1$} \\
\hline $\mathrm{T} 2$ & $\times$ & & & & & \\
\hline T3 & & $\times$ & & & & \\
\hline $\mathrm{T} 4$ & & & $x$ & & & \\
\hline T5 & & & & $\times$ & & \\
\hline T6 & & & & & $x$ & \\
\hline $\mathrm{T} 7$ & & & & & & $\times$ \\
\hline
\end{tabular}

${ }^{1} \mathrm{WPC}=$ Whey protein concentrate $\mathrm{MPC}=$ milk protein concentrate. ${ }^{2}$ Treatments: $\mathrm{T} 1=$ control; $\mathrm{T} 2=30 \%$ increase in protein from added $\mathrm{WPC} ; \mathrm{T} 3=60 \%$ increase in protein from added $\mathrm{WPC} ; \mathrm{T} 4=90 \%$ increase in protein from added WPC; $\mathrm{T} 5=30 \%$ increase in protein from added MPC; T6 $=60 \%$ increase in protein from added MPC; $\mathrm{T} 7=90 \%$ increase in protein from added MPC.

is higher in protein than normal ice cream. Ice cream mix composition and characteristics, as well as ice cream characteristics and sensory properties, were evaluated.

\section{MATERIALS AND METHODS}

\section{Manufacture of Ice Cream Mix}

Ice cream mix contained $10.5 \%$ milk fat (fat source was milk and cream; Wells' Dairy, Inc., LeMars, IA), $10.5 \%$ milk SNF (milk SNF sources were cream and condensed skim milk, Wells' Dairy, Inc.), $12 \%$ beet sugar (Wells' Dairy, Inc.), and 4\% 36 dextrose-equivalent corn syrup solids (Roquette America Inc., Keokuk, IA). Seven ice cream treatments were targeted to contain $37 \%$ TS. Stabilizers and emulsifiers were not added to any treatments. The control (T1) contained $3.78 \%$ protein and was not supplemented with WPC or MPC. Treatments 2, 3, and 4 (T2, T3, and T4, respectively) were supplemented with WPC (82.5\% protein, Grade A lactalbumin, Leprino Foods, Denver, CO) and contained 30,60 , or $90 \%$ increased protein level, respectively, compared with T1. Treatments 5, 6, and 7 (T5, T6, and T7) were supplemented with MPC (70.0\% protein, Milk Protein Concentrate 70, Murray Goulburn Cooperative Co. Ltd., Melbourne, Australia) and contained 30, 60, or $90 \%$ increased protein level, respectively, compared with T1 (Table 1). Three replications were performed for a total of 21 ice creams manufactured. Fat and total solids for milk, cream, and condensed skim milk were analyzed by CEM Smart Trac (CEM Corp., Matthews, NC). Ice cream mix was made in 7 batches and each batch of $45.4 \mathrm{~kg}$ represented 1 treatment (Table 1 ). Ice cream mixes were made by first heating the liquid ingredients (cream, milk, condensed skim milk, and water) to $44^{\circ} \mathrm{C}$ in an ice cream mix tank (Technogel Universal Pilot Plant, Italy). Other ingredients (beet sugar, corn syrup solids, and WPC or MPC) were added at this point, and mixed for 10 to 15 min. Mixes were pasteurized by HTST at $82^{\circ} \mathrm{C}$ for $25 \mathrm{~s}$ (Processing Machinery and Supply Co., Philadelphia, PA), and homogenized on a Gaulin APV Schroder homogenizer (Albertslund, Denmark) with $141 \mathrm{~kg} / \mathrm{cm}^{2}$ pressure on the first stage, and $35 \mathrm{~kg} / \mathrm{cm}^{2}$ pressure on the second. Mixes were cooled and stored at $4^{\circ} \mathrm{C}$ overnight.

\section{Ice Cream Mix Analysis}

Ice cream mixes were analyzed for fat and TS in duplicate by the Mojonnier method (Atherton and Newlander, 1977). Ice cream mix was analyzed in duplicate for total $\mathrm{N}$ by the Kjeldahl method (991.20; AOAC, 2002). Protein was determined by multiplying total $N$ by a factor of 6.38 . The procedure was modified according to the amount of protein in the ice cream mix. For the control (T1) ice cream mix, $5.0 \mathrm{~g}$ was weighed; for $\mathrm{T} 2$ and $\mathrm{T} 5$ containing a 30\% increase in protein, 3.5 $\mathrm{g}$ was weighed; for T3 and T6 containing a $60 \%$ increase in protein, $3.0 \mathrm{~g}$ was weighed; and for $\mathrm{T} 4$ and $\mathrm{T} 7 \mathrm{con}-$ taining a $90 \%$ increase in protein, $2.5 \mathrm{~g}$ was weighed. The $\mathrm{pH}$ was measured with a Corning model $350 \mathrm{pH}$ analyzer (Corning Inc., Corning, NY) and titratable acidity, expressed as percentage lactic acid, was determined adding $0.1 \mathrm{~N} \mathrm{NaOH}$ to the phenolphthalein end point (Atherton and Newlander, 1977). Freezing points of mixes were determined in triplicate by the osmometer method (Baer and Czmowski, 1985), and ash content of mixes, WPC, and MPC were determined in duplicate (method 945.46; AOAC, 2002). Lactose content of mix was determined by difference wherein milk fat, protein, ash, beet sugar, and corn syrup solids were deducted from TS content.

A bob and cup attachment was fixed to the viscoanalyzer (ATS Rheosystems, Rheologica Instruments AB, Lund, Sweden) that was further connected to a computer and kept on standby at designed parameters for determination of viscosity of the mix. The shear rate sweep was set at 1 to $200 \mathrm{~s}^{-1}$ in $20 \mathrm{~s}$. Ten milliliters of mix was accurately measured, transferred into a viscometer cup, and allowed to stand until it attained $10^{\circ} \mathrm{C}$. Once the temperature was reached, the preshear was given at a shear rate of $11 \mathrm{~s}^{-1}$, which was followed by equilibrium time of $20 \mathrm{~s}$. Viscosity measurement of the mix started when the data were collected at an interval of $2 \mathrm{~s}$ with zero gapping. Viscosity values were calculated at $100 \mathrm{~s}^{-1}$ shear rate for each treatment and reported in tabular form. Between the 2 sample analyses, the spindle was detached from the assembly, rinsed with distilled water, dried, and remounted on the assembly. 


\section{Ice Cream Manufacture}

Real 2-fold vanilla extract (Mother Murphy's Laboratories, Inc., Greensboro, NC) was added at a rate of $229.3 \mathrm{~mL}$ per $45.4 \mathrm{~kg}$ of ice cream mix prior to freezing. Ice cream mix was frozen in a continuous freezer with a target of 90\% overrun (Gram Equipment, Sidan, Italy). Overrun was calculated on a weight basis (Arbuckle, 1986). A digital thermometer was used to measure drawing temperature of the ice cream upon extrusion from the continuous freezer and the ice cream was collected in a 454-g plastic container (Sweetheart Cup Co., Inc., Owings Mills, MD). Ice cream was placed in a blast freezer for $2 \mathrm{~h}$ at $-29.5^{\circ} \mathrm{C}$, stored in a hardening room at $-28^{\circ} \mathrm{C}$, and analyzed for ice crystal size and sensory evaluation at $1 \mathrm{wk}$ postmanufacture.

\section{Analysis of Ice Crystal Size}

A light microscope (Olympus BH-2, Olympus Optical Co., Ltd., Tokyo, Japan) was used to determine the mean ice crystal size of the ice creams (Ruger et al., 2002). Ice creams were prepared by the squash mount method (Berger and White, 1979) using a 50:50 mixture of amyl alcohol and kerosene. Ice crystal sizes were determined at $-18^{\circ} \mathrm{C}$ by measuring each ice crystal at its widest point using an eyepiece micrometer. At least 150 ice crystals were counted for each sample. The ice creams, microscope, utensils, and mounting medium were tempered in a walk-in freezer at $-18^{\circ} \mathrm{C}$ before examination.

\section{Sensory Evaluation}

A 4-member experienced sensory panel from South Dakota State University evaluated 3-digit randomly coded ice creams for flavor and texture (Larmond, 1977). Iciness, coldness intensity, creaminess, sweetness, and vanilla flavor intensity scoring was done on a scale of 1 to 9 ( $1=$ none, $5=$ definite, and $9=$ pronounced). Overall texture acceptance and overall flavor acceptance scoring was done on a scale of 1 to $9(1=$ dislike extremely, $3=$ dislike moderately, $5=$ neither like nor dislike, 7 = like moderately, and $9=$ like extremely). Two sensory score sheets were used, one for normal ice cream samples after hardening, and the other for heat-shocked samples. Stability to heat shock was evaluated by the freeze-thaw method after manufacture (Arbuckle, 1986). Ice cream was dispensed in a 454-g plastic container, tempered, and stored at -17 to $-15^{\circ} \mathrm{C}$. It was removed from storage, held at 20 to $21^{\circ} \mathrm{C}$ for $30 \mathrm{~min}$, and returned to the freezer $\left(-17\right.$ to $\left.-15^{\circ} \mathrm{C}\right)$. The next day, it was removed from storage and held at 20 to $21^{\circ} \mathrm{C}$ for $60 \mathrm{~min}$; this treatment was repeated for
Table 2. Ice cream mix composition ${ }^{1}$

\begin{tabular}{|c|c|c|c|c|c|}
\hline Treatment $^{2}$ & $\begin{array}{l}\text { Milk } \\
\text { fat }\end{array}$ & $\mathrm{TS}$ & Protein & Ash & Lactose $^{3}$ \\
\hline & & & $-\%$ & & \\
\hline $\mathrm{T} 1$ & $10.56^{\mathrm{a}}$ & $37.01^{\mathrm{a}}$ & $3.78^{d}$ & $0.86^{\mathrm{a}}$ & $5.80^{\mathrm{a}}$ \\
\hline $\mathrm{T} 2$ & $10.52^{\mathrm{a}}$ & $37.01^{\mathrm{a}}$ & $4.91^{c}$ & $0.70^{c}$ & $4.87^{\mathrm{b}}$ \\
\hline T3 & $10.53^{a}$ & $37.03^{\mathrm{a}}$ & $6.05^{\mathrm{b}}$ & $0.51^{\mathrm{d}}$ & $3.92^{\mathrm{c}}$ \\
\hline $\mathrm{T} 4$ & $10.55^{\mathrm{a}}$ & $37.01^{\mathrm{a}}$ & $7.18^{\mathrm{a}}$ & $0.47^{\mathrm{d}}$ & $2.79^{\mathrm{e}}$ \\
\hline T5 & $10.53^{\mathrm{a}}$ & $37.00^{\mathrm{a}}$ & $4.90^{\mathrm{c}}$ & $0.80^{\mathrm{ab}}$ & $4.76^{\mathrm{b}}$ \\
\hline T6 & $10.54^{\mathrm{a}}$ & $37.00^{\mathrm{a}}$ & $6.05^{\mathrm{b}}$ & $0.77^{\mathrm{b}}$ & $3.63^{\mathrm{d}}$ \\
\hline $\mathrm{T} 7$ & $10.57^{\mathrm{a}}$ & $37.02^{\mathrm{a}}$ & $7.18^{\mathrm{a}}$ & $0.76^{\mathrm{bc}}$ & $2.50^{f}$ \\
\hline
\end{tabular}

${ }^{\mathrm{a}-\mathrm{f}}$ Means in the same column without common superscripts differ $(P<0.05)$.

${ }^{1}$ Mean of 3 replicates.

${ }^{2}$ Treatments: $\mathrm{T} 1=$ control; $\mathrm{T} 2=30 \%$ increase in protein from added whey protein concentrate (WPC); T3 $=60 \%$ increase in protein from added WPC; T4 $=90 \%$ increase in protein from added WPC; T5 = $30 \%$ increase in protein from added milk protein concentrate (MPC); $\mathrm{T} 6=60 \%$ increase in protein from added MPC; T7 $=90 \%$ increase in protein from added MPC.

${ }^{3}$ Lactose determined by difference.

$5 \mathrm{~d}$. Sensory analysis (only texture) of the heat-shocked samples was conducted.

\section{Statistical Analysis}

Data analyses were done using the GLM procedure (SAS Institute, 1999). Completely randomized design was used to evaluate the effect of individual treatments. Significance was determined by Fisher's least significant difference at $P<0.05$.

\section{RESULTS AND DISCUSSION}

\section{Ice Cream Mix Composition}

Milk fat content of ice cream mix was similar among all treatments, ranging from 10.52 to $10.57 \%$ (Table 2). Adding milk fat to ice cream mix at the expense of water lowers the ice phase volume of the ice cream and provides a smoother product (Hartel, 1996). Increasing the milk fat content in ice cream will provide richness in mouth feel (Keeney, 1979; Arbuckle, 1986) and also reduce ice crystal size (Keeney and Kroger, 1974).

Total solids were targeted at $37 \%$, ranged from 37.00 to $37.03 \%$, and were similar among treatments (Table 2 ). When hardening to the same storage temperature, more water has to be frozen for ice cream mix with low TS compared with ice cream mix with high TS, which has comparatively less water content. Ice crystal size distribution is related to TS in ice cream (Flores and Goff, 1999). Ice cream with less TS had larger ice crystals (Donhowe et al., 1991).

Ice cream contains a high concentration of milk SNF, which is 34 to $36 \%$ protein. Treatment 1 had a protein 
level of $3.78 \%$ (Table 2); typically, ice cream has a protein content of about $3.61 \%$ (USDA, 1976). Protein levels were similar between $\mathrm{T} 2$ and $\mathrm{T} 5$, $\mathrm{T} 3$ and $\mathrm{T} 6$, and $\mathrm{T} 4$ and T7. This was as expected because T2 was increased in protein by $29.89 \%$, T5 by $29.63 \%$, T3 and $\mathrm{T} 6$ by $60.05 \%$, and $\mathrm{T} 4$ and $\mathrm{T} 7$ by $89.95 \%$, compared with T1. Protein content of ice cream mix was lower $(P<0.05)$ for T1 compared with all other treatments. Proteins contribute to the development of structure in ice cream, including emulsification, whipping, and water-holding capacity (Schmidt, 1994; Walstra and Jonkman, 1998). Foaming is important during the manufacture of ice cream and milk proteins are well known for their ability to form foams. Thus, milk proteins contribute to stabilizing the air interface in ice cream, an important factor for overall structure and structural stability (Turan et al., 1999).

Ash content of ice cream mix ranged from 0.47 to $0.86 \%$ among all treatments (Table 2). A trend of reduction in ash content was observed as the protein content of the mix was increased. Ash content was reduced more in WPC treatments compared with MPC treatments. Whey protein concentrate powder had an ash content of $2.79 \%$, whereas MPC powder had an ash content of $7.16 \%$. Ice cream mix lactose content was different $(P$ $<0.05$ ) among all treatments except for T2 and T5, with lactose content decreasing as protein increased. Whey protein concentrate with a lower lactose concentration should allow for usage at higher levels without increasing development of sandiness in the ice cream (Parsons et al., 1985). Ash and lactose contents also varied in the ice cream mix treatments because protein content was varied and TS content was kept constant at $37.0 \%$.

\section{Ice Cream Mix Characteristics}

Ice cream mix $\mathrm{pH}$ values ranged from 6.57 to 6.77 with differences $(P<0.05)$ between T4 and T7 (Table 3 ). Treatment 1 and the WPC treatments had similar $\mathrm{pH}$ values. Ice cream mix $\mathrm{pH}$ can be used as an indicator of microbial quality (Arbuckle, 1986). Milk SNF content is related to $\mathrm{pH}$ of ice cream mix; as the milk SNF portion of a mix increases, the normal acidity is elevated and the $\mathrm{pH}$ is lowered (Arbuckle, 1986).

Ice cream mix titratable acidity values ranged from 0.19 to $0.22 \%$ with a lower $(P<0.05)$ value for $\mathrm{T} 1$ and $\mathrm{T} 2$ compared with all other treatments (Table 3). Apparent titratable acidity in milk is dependent on $\mathrm{CN}$, albumin, phosphates, citrates, and carbon dioxide (Atherton and Newlander, 1977). As protein content of ice cream mix was increased, the titratable acidity increased, because the $\mathrm{CN}$ and albumin are also increased.

The freezing point determination of ice cream mix will detect variation in the amount of solute present in
Table 3. Ice cream mix characteristics ${ }^{1}$

\begin{tabular}{lllll}
\hline & & $\begin{array}{l}\text { Titratable } \\
\text { acidity } \\
(\%)\end{array}$ & $\begin{array}{l}\text { Freezing } \\
\text { point } \\
\left({ }^{\circ} \mathrm{C}\right)\end{array}$ & $\begin{array}{l}\text { Viscosity } \\
(\mathrm{Pa} \cdot \mathrm{s})\end{array}$ \\
\hline $\mathrm{T} 1$ & $\mathrm{pH}$ & $0.19^{\mathrm{d}}$ & $-2.33^{\mathrm{d}}$ & $0.27^{\mathrm{c}}$ \\
$\mathrm{T} 2$ & $6.64^{\mathrm{bc}}$ & $-20^{\mathrm{cd}}$ & $-2.22^{\mathrm{c}}$ & $0.06^{\mathrm{d}}$ \\
$\mathrm{T} 3$ & $6.64^{\mathrm{bc}}$ & $0.21^{\mathrm{abc}}$ & $-2.14^{\mathrm{bc}}$ & $0.81^{\mathrm{a}}$ \\
$\mathrm{T} 4$ & $6.58^{\mathrm{c}}$ & $-2.00^{\mathrm{a}}$ & $0.70^{\mathrm{b}}$ \\
$\mathrm{T} 5$ & $6.57^{\mathrm{c}}$ & $0.22^{\mathrm{a}}$ & $-2.20^{\mathrm{c}}$ & $0.04^{\mathrm{d}}$ \\
T6 & $6.62^{\mathrm{bc}}$ & $0.21^{\mathrm{bc}}$ & $-2.11^{\mathrm{b}}$ & $0.12^{\mathrm{d}}$ \\
T7 & $6.70^{\mathrm{ab}}$ & $0.21^{\mathrm{abc}}$ & $-1.94^{\mathrm{a}}$ & $0.22^{\mathrm{c}}$ \\
\hline
\end{tabular}

${ }^{\mathrm{a}-\mathrm{d}}$ Means in the same column without common superscripts differ $(P<0.05)$

${ }^{1}$ Mean of 3 replicates.

${ }^{2}$ Treatments: $\mathrm{T} 1=$ control; $\mathrm{T} 2=30 \%$ increase in protein from added whey protein concentrate (WPC); T3 $=60 \%$ increase in protein from added WPC; T4 $=90 \%$ increase in protein from added WPC; T5 = $30 \%$ increase in protein from added milk protein concentrate (MPC); $\mathrm{T} 6=60 \%$ increase in protein from added MPC; $\mathrm{T} 7=90 \%$ increase in protein from added MPC.

samples (Baer and Czmowski, 1985). Ice cream mix freezing point is a reflection of the number of molecules in solution, with the most prevalent constituent being sugar (Arbuckle, 1986). Variations in freezing points can alter the recrystallization rate at a specific storage temperature in ice cream (Wittinger and Smith, 1986; Hagiwara and Hartel, 1996). Ice cream mix freezing points ranged from -1.94 to $-2.33^{\circ} \mathrm{C}$ and were different $(P<0.05)$ with some treatments (Table 3$)$. Treatment 1 had the lowest $(P<0.05)$ freezing point, because it contained the highest concentration of substances in solution compared with all other treatments. Freezing points of $\mathrm{T} 2$ and $\mathrm{T} 5, \mathrm{~T} 3$ and $\mathrm{T} 6$, and $\mathrm{T} 4$ and $\mathrm{T} 7$ were similar.

Viscosity is defined as the resistance to flow. One percent WPC substituted for 1\% NDM had no effect on ice cream mix viscosity (Ruger et al., 2002). Ice cream mix viscosities ranged from 0.27 to $0.81 \mathrm{~Pa} \cdot \mathrm{s}$ at $10^{\circ} \mathrm{C}$ and were different $(P<0.05)$ with some treatments (Table 3). Treatment 3 had the highest $(P<0.05)$ viscosity and $\mathrm{T} 2$, T5, and $\mathrm{T} 6$ had the lowest viscosity among all other treatments. The MPC treatments had viscosities lower than or similar to $\mathrm{T} 1$.

\section{Ice Cream Characteristics}

Draw temperature directly measures the rate of heat removal from ice cream and can be used to estimate the ice phase volume of the ice cream upon extrusion from the freezer, ensuring that it follows the freezing point depression curve (Bradley, 1984). Smooth ice cream will be produced if the majority of the ice phase volume is formed in initial freezing when nucleation takes place and many small ice crystals are formed (Hartel, 1996). Draw temperature ranged $(P<0.05)$ 
Table 4. Ice cream characteristics ${ }^{1}$

\begin{tabular}{llll}
\hline & $\begin{array}{l}\text { Draw } \\
\text { temperature } \\
\text { Treatment }^{2}\end{array}$ & $\begin{array}{l}\text { Overrun } \\
(\%)\end{array}$ & $\begin{array}{l}\text { Ice } \\
\text { crystals } \\
(\mu \mathrm{m})\end{array}$ \\
\hline $\mathrm{T} 1$ & $-5.2^{\mathrm{c}}$ & $88.91^{\mathrm{ab}}$ & $40.79^{\mathrm{a}}$ \\
$\mathrm{T} 2$ & $-4.5^{\mathrm{ab}}$ & $90.42^{\mathrm{ab}}$ & $35.08^{\mathrm{b}}$ \\
$\mathrm{T} 3$ & $-4.5^{\mathrm{ab}}$ & $86.58^{\mathrm{b}}$ & $36.56^{\mathrm{ab}}$ \\
$\mathrm{T} 4$ & $-4.6^{\mathrm{b}}$ & $92.17^{\mathrm{a}}$ & $36.18^{\mathrm{b}}$ \\
$\mathrm{T} 5$ & $-4.5^{\mathrm{ab}}$ & $92.93^{\mathrm{a}}$ & $35.94^{\mathrm{b}}$ \\
$\mathrm{T} 6$ & $-4.2^{\mathrm{ab}}$ & $89.19^{\mathrm{ab}}$ & $37.72^{\mathrm{ab}}$ \\
T7 & $-4.0^{\mathrm{a}}$ & $92.08^{\mathrm{a}}$ & $37.45^{\mathrm{ab}}$ \\
\hline
\end{tabular}

${ }^{\mathrm{a}-\mathrm{c}}$ Means in the same column without common superscripts differ $(P<0.05)$.

${ }^{1}$ Mean of 3 replicates.

${ }^{2}$ Treatments: $\mathrm{T} 1=$ control; $\mathrm{T} 2=30 \%$ increase in protein from added whey protein concentrate (WPC); T3 $=60 \%$ increase in protein from added WPC; $\mathrm{T} 4=90 \%$ increase in protein from added WPC; $\mathrm{T} 5=$ $30 \%$ increase in protein from added milk protein concentrate (MPC); $\mathrm{T} 6=60 \%$ increase in protein from added MPC; T7 $=90 \%$ increase in protein from added MPC.

from $-5.2^{\circ} \mathrm{C}$ in $\mathrm{T} 1$ to $-4.0^{\circ} \mathrm{C}$ in $\mathrm{T} 7$ (Table 4). Treatment 1 had the lowest draw temperature of the treatments, which was possibly due to its low freezing point. Draw temperatures of ice cream made in a continuous freezer have been reported to average $-5.6^{\circ} \mathrm{C}$ (Arbuckle, 1986).

An increase in volume of ice cream over the volume of ice cream mix due to incorporation of air is the overrun (Marshall and Arbuckle, 1996). Overrun ranged from $86.58 \%$ in T3 to $92.93 \%$ in T5 (Table 4). Overrun was targeted at $90 \%$ and was similar in all treatments except T3. It can be difficult to control overrun when manufacturing small batches of ice cream. An increase in overrun decreases the size of ice crystals in ice cream (Marshall and Arbuckle, 1996) and greater dispersion of air cells reduces the chance of collisions between ice crystals (Flores and Goff, 1999).

Ice crystal size plays a major role in influencing the texture of ice cream (Hartel, 1996). Mean ice crystal size in ice creams ranged from $35.08 \mu \mathrm{m}$ in $\mathrm{T} 2$ to 40.79 $\mu \mathrm{m}$ in $\mathrm{T} 1$ (Table 4). Ice cream with increased protein content had ice crystals that were smaller $(P<0.05)$ and more desirable in $\mathrm{T} 2, \mathrm{~T} 4$, and $\mathrm{T} 5$, compared with T1. Whey proteins and CN have good water-binding capacity; hence, less free water is available to form ice crystals, possibly resulting in the formation of smaller ice crystals in ice cream. Recently, ice-structuring proteins (from arctic fish or winter wheat) have been used to inhibit ice crystal growth and maintain uniformly small ice crystals in ice cream (Marshall et al., 2003). Proteins adsorb firmly onto the ice crystal surface and prevent further growth, thereby preventing formation of larger ice crystals.

Ice crystals measured within each treatment were divided into 4 size categories (size $1=10$ to $25 \mu \mathrm{m}$, size $2=26$ to $40 \mu \mathrm{m}$, size $3=41$ to $55 \mu \mathrm{m}$, and size $4=$
Table 5. Distribution as percentage of ice crystals in different size categories of ice cream ${ }^{1}$

\begin{tabular}{llllr}
\hline & \multicolumn{4}{c}{ Size category $^{2}$} \\
\cline { 2 - 5 } Treatment $^{3}$ & 1 & 2 & 3 & \multicolumn{1}{c}{4} \\
\hline & & & & \\
\cline { 2 - 5 } T1 & $14.67^{\mathrm{b}}$ & $35.88^{\mathrm{b}}$ & $38.39^{\mathrm{a}}$ & $11.04^{\mathrm{a}}$ \\
T2 & $24.66^{\mathrm{ab}}$ & $46.87^{\mathrm{a}}$ & $25.06^{\mathrm{b}}$ & $3.39^{\mathrm{a}}$ \\
T3 & $25.27^{\mathrm{a}}$ & $42.57^{\mathrm{ab}}$ & $24.12^{\mathrm{b}}$ & $8.03^{\mathrm{a}}$ \\
T4 & $23.25^{\mathrm{ab}}$ & $44.88^{\mathrm{ab}}$ & $27.99^{\mathrm{ab}}$ & $3.86^{\mathrm{a}}$ \\
T5 & $26.12^{\mathrm{a}}$ & $41.46^{\mathrm{ab}}$ & $29.21^{\mathrm{ab}}$ & $3.20^{\mathrm{a}}$ \\
T6 & $19.20^{\mathrm{ab}}$ & $42.71^{\mathrm{ab}}$ & $32.57^{\mathrm{ab}}$ & $5.51^{\mathrm{a}}$ \\
T7 & $16.94^{\mathrm{ab}}$ & $48.41^{\mathrm{a}}$ & $30.81^{\mathrm{ab}}$ & $3.83^{\mathrm{a}}$ \\
\hline
\end{tabular}

${ }^{\mathrm{a}, \mathrm{b}}$ Means in the same column without common superscripts differ $(P<0.05)$.

${ }^{1}$ Mean of 3 replicates.

${ }^{2}$ Ice crystal size categories: $1=10$ to $25 \mu \mathrm{m} ; 2=26$ to $40 \mu \mathrm{m} ; 3=$ 41 to $55 \mu \mathrm{m}$; and $\geq 56 \mu \mathrm{m}$.

${ }^{3}$ Treatments: $\mathrm{T} 1$ = control; $\mathrm{T} 2=30 \%$ increase in protein from added whey protein concentrate (WPC); $\mathrm{T} 3=60 \%$ increase in protein from added WPC; T4 $=90 \%$ increase in protein from added WPC; T5 = $30 \%$ increase in protein from added milk protein concentrate (MPC); $\mathrm{T} 6=60 \%$ increase in protein from added MPC.

$\geq 56 \mu \mathrm{m})$ and the percentage of ice crystals in each size category were calculated (Table 5). Treatments 3 and 5 had a higher $(P<0.05)$ percentage of ice crystals in size category 1 compared with T1. Hartel (1996) suggested that, rather than using the mean ice crystal size to evaluate iciness, it should be based on the number of ice crystals over a threshold detection level. No increase in iciness development was apparent when MPC were evaluated as substitutes for 20 and $50 \%$ of the protein content in ice cream mix in place of NDM, suggesting that MPC could be incorporated to produce a suitable ice cream (Alvarez et al., 2005). Direct count of ice crystals is the best way to objectively quantify the texture of ice cream; however, this does not take into account all aspects of sensory perception. Sensory evaluation of the texture of ice cream involves the distribution and volume of air cells (Arbuckle, 1986), the lubricating effect of fat as it melts on the pallet (Marshall and Arbuckle, 1996), and many other factors in addition to ice crystal size and distribution.

Shrinkage (air cell collapse) defect was visually observed in T7 after heat shock, wherein the ice cream was not in full contact with the side of the container. Shrinkage results from a loss of discrete air bubbles as they coalesce and begin to form continuous channels, eventually leading to collapse of the product itself into the channels (Turan et al., 1999). Temperature fluctuations accentuate the shrinkage defect by allowing the supporting structure of ice to melt and refreeze, causing pressure on air cells to change (Marshall et al., 2003). The high protein content of T7 possibly caused destabilization of air cells, which is surprising because milk 
Table 6. Texture and flavor scores of ice cream at $1 \mathrm{wk}$ postmanufacture ${ }^{1}$

\begin{tabular}{|c|c|c|c|c|c|c|c|}
\hline Treatment $^{2}$ & Iciness $^{3}$ & $\begin{array}{l}\text { Coldness } \\
\text { intensity }^{3}\end{array}$ & Creaminess $^{3}$ & $\begin{array}{l}\text { Overall } \\
\text { texture } \\
\text { acceptance }^{4}\end{array}$ & Sweetness $^{3}$ & $\begin{array}{l}\text { Vanilla } \\
\text { flavor } \\
\text { intensity }\end{array}$ & $\begin{array}{l}\text { Overall } \\
\text { flavor } \\
\text { acceptance }^{4}\end{array}$ \\
\hline $\mathrm{T} 1$ & $5.50^{\mathrm{a}}$ & $6.16^{\mathrm{a}}$ & $4.25^{\mathrm{a}}$ & $3.91^{\mathrm{b}}$ & $5.00^{\mathrm{a}}$ & $4.66^{\mathrm{ab}}$ & $6.58^{\mathrm{a}}$ \\
\hline $\mathrm{T} 2$ & $4.25^{\mathrm{b}}$ & $5.08^{\mathrm{b}}$ & $4.83^{\mathrm{a}}$ & $6.00^{\mathrm{a}}$ & $4.91^{\mathrm{a}}$ & $4.75^{\mathrm{ab}}$ & $6.25^{\mathrm{ab}}$ \\
\hline T3 & $4.08^{\mathrm{b}}$ & $4.50^{\mathrm{b}}$ & $4.50^{\mathrm{a}}$ & $5.66^{\mathrm{a}}$ & $4.50^{\mathrm{a}}$ & $4.25^{\mathrm{bc}}$ & $5.75^{\mathrm{b}}$ \\
\hline $\mathrm{T} 4$ & $3.91^{\mathrm{b}}$ & $5.00^{\mathrm{b}}$ & $4.33^{\mathrm{a}}$ & $5.83^{\mathrm{a}}$ & $4.41^{\mathrm{a}}$ & $3.66^{\mathrm{c}}$ & $3.08^{\mathrm{c}}$ \\
\hline T5 & $4.08^{b}$ & $5.33^{\mathrm{ab}}$ & $4.50^{\mathrm{a}}$ & $5.50^{\mathrm{a}}$ & $5.08^{\mathrm{a}}$ & $5.08^{\mathrm{a}}$ & $6.50^{\mathrm{a}}$ \\
\hline T6 & $4.50^{\mathrm{b}}$ & $5.08^{\mathrm{b}}$ & $4.33^{\mathrm{a}}$ & $5.50^{\mathrm{a}}$ & $4.91^{\mathrm{a}}$ & $4.75^{\mathrm{ab}}$ & $6.25^{\mathrm{ab}}$ \\
\hline $\mathrm{T} 7$ & $3.83^{b}$ & $4.50^{\mathrm{b}}$ & $4.75^{\mathrm{a}}$ & $6.16^{\mathrm{a}}$ & $4.41^{\mathrm{a}}$ & $5.08^{\mathrm{a}}$ & $5.75^{\mathrm{b}}$ \\
\hline
\end{tabular}

${ }^{\mathrm{a}-\mathrm{c}}$ Means in the same column without common superscripts differ $(P<0.05)$.

${ }^{1}$ Mean of 3 replicates.

${ }^{2}$ Treatment: $\mathrm{T} 1=$ control; $\mathrm{T} 2=30 \%$ increase in protein from added whey protein concentrate $(\mathrm{WPC})$; $\mathrm{T} 3=$ $60 \%$ increase in protein from added WPC; T4 $=90 \%$ increase in protein from added WPC; $\mathrm{T} 5=30 \%$ increase in protein from added milk protein concentrate (MPC); $\mathrm{T} 6=60 \%$ increase in protein from added MPC; $\mathrm{T} 7=$ $90 \%$ increase in protein from added MPC.

${ }^{3} 1=$ none, $5=$ definite, and $9=$ pronounced.

${ }^{4} 1$ = dislike extremely, 3 = dislike moderately, 5 = neither like nor dislike, 7 = like moderately, and $9=$ like extremely.

proteins stabilize the air cell interface (Turan et al., 1999).

\section{Sensory Evaluation of Ice Cream}

Sensory evaluation scores for ice cream treatments at $1 \mathrm{wk}$ postmanufacture and heat-shocked ice cream are given in Tables 6 and 7. Icy texture scores were lower $(P<0.05)$ (more desirable) at $1 \mathrm{wk}$ postmanufacture for all treatments compared with T1 (Table 6) and were more desirable in heat-shocked treatments (T3, T4, T5, T6, and T7) compared with $\mathrm{T} 1$ and $\mathrm{T} 2$ (Table 7). Coldness intensity of all ice creams with increased

Table 7. Texture scores ${ }^{1}$ of heat-shocked ice cream

\begin{tabular}{|c|c|c|c|c|}
\hline Treatment $^{2}$ & Iciness $^{3}$ & $\begin{array}{l}\text { Coldness }{ }^{3} \\
\text { intensity }\end{array}$ & Creaminess $^{3}$ & $\begin{array}{l}\text { Overall } \\
\text { texture } \\
\text { acceptance }^{4}\end{array}$ \\
\hline $\mathrm{T} 1$ & $7.58^{\mathrm{a}}$ & $7.50^{\mathrm{a}}$ & $4.41^{\mathrm{a}}$ & $4.58^{\mathrm{a}}$ \\
\hline $\mathrm{T} 2$ & $6.66^{\mathrm{ab}}$ & $7.33^{\mathrm{ab}}$ & $4.50^{\mathrm{a}}$ & $4.83^{\mathrm{a}}$ \\
\hline T3 & $5.83^{\mathrm{bc}}$ & $5.58^{\mathrm{cd}}$ & $4.41^{\mathrm{a}}$ & $4.58^{\mathrm{a}}$ \\
\hline $\mathrm{T} 4$ & $5.83^{b c}$ & $5.91^{\mathrm{cd}}$ & $5.16^{\mathrm{a}}$ & $5.33^{\mathrm{a}}$ \\
\hline T5 & $5.91^{b c}$ & $6.41^{\mathrm{bc}}$ & $3.75^{\mathrm{a}}$ & $4.33^{\mathrm{a}}$ \\
\hline T6 & $5.25^{\mathrm{c}}$ & $5.66^{\text {cd }}$ & $5.33^{\mathrm{a}}$ & $5.16^{\mathrm{a}}$ \\
\hline $\mathrm{T} 7$ & $5.16^{\mathrm{c}}$ & $5.33^{\mathrm{d}}$ & $5.58^{\mathrm{a}}$ & $4.25^{\mathrm{a}}$ \\
\hline
\end{tabular}

${ }^{\mathrm{a}-\mathrm{d}}$ Means in the same column without common superscripts differ $(P<0.05)$.

${ }^{1}$ Mean of 3 replicates.

${ }^{2}$ Treatments: $\mathrm{T} 1=$ control; $\mathrm{T} 2=30 \%$ increase in protein from added whey protein concentrate (WPC); T3 $=60 \%$ increase in protein from added WPC; T4 $=90 \%$ increase in protein from added WPC; T5 = $30 \%$ increase in protein from added milk protein concentrate (MPC); $\mathrm{T} 6=60 \%$ increase in protein from added MPC; $\mathrm{T} 7=90 \%$ increase in protein from added MPC.

${ }^{3} 1=$ none, $5=$ definite, and $9=$ pronounced.

${ }^{4} 1$ = dislike extremely, 3 = dislike moderately, 5 = neither like nor dislike, 7 = like moderately, and 9 = like extremely. protein levels had lower $(P<0.05)$, more desirable scores, than $\mathrm{T} 1$ at 1 wk postmanufacture (Table 6), whereas heat-shocked samples (T1 and T2) had the highest, most undesirable, scores compared with all other treatments. Creaminess scores among all treatments were similar at $1 \mathrm{wk}$ postmanufacture and in heat-shocked ice creams. At 1 wk postmanufacture, all treatments were preferred $(P<0.05)$ for overall texture acceptance compared with T1. Heat-shocked ice creams for all treatments had similar scores for overall texture acceptance (Table 7).

Sweetness flavor scores were similar among all treatments at $1 \mathrm{wk}$ postmanufacture (Table 6 ). Vanilla flavor intensity for T4 was found to have lower $(P<0.05)$ scores among all treatments except for T3 at 1 wk postmanufacture. Treatment 4 had lower vanilla flavor intensity compared with $\mathrm{T} 1$, which indicated that the higher levels of WPC masked flavor. When using WPC at high levels to increase protein content, more vanilla flavor would need to be added to ice cream. However, all MPC treatments had similar vanilla flavor intensity compared with T1. Overall flavor acceptance scores showed the same trend, with T4 having the lowest ( $P$ $<0.05)$ scores among all treatments. Also, T3 and T7 had a lower $(P<0.05)$ overall flavor acceptance scores compared with $\mathrm{T} 1$.

\section{CONCLUSIONS}

Ice cream higher in protein was successfully manufactured by adding WPC or MPC. Milk fat content of ice cream mix ranged from 10.52 to $10.57 \%$, and TS ranged from 37.00 to $37.03 \%$; both were similar among all treatments. Protein levels were similar between T2 and T5 (4.91 and 4.90\%), between T3 and T6 (both 
6.05\%), and between $\mathrm{T} 4$ and $\mathrm{T} 7$ (both $7.18 \%$ ) with $\mathrm{T} 1$ having $3.78 \%$ protein. Lactose content decreased among treatments as protein increased. Ice crystal size was smaller in T2, T4, and T5, and similar in T3, T6, and $\mathrm{T} 7$ compared with T1. Viscosity was lower for T2, T5, and T6 and higher for T3 and T4 compared with T1. Panelists reported lower overall texture acceptance scores between $\mathrm{T} 1$ and all other treatments in ice creams at wk 1 postmanufacture, whereas the heatshocked ice creams had similar texture acceptance scores among all treatments. Overall flavor acceptance scores were lowest for T4 due to a whey off-flavor. Treatment 2 with added WPC and T5 and T6 with added MPC were similar or improved compared with $\mathrm{T} 1$ after evaluating all parameters.

Future research needs to evaluate why T7 with the highest level of MPC exhibited shrinkage defect after heat shock. This defect might be prevented by addition of different combinations of stabilizers, emulsifiers, or both to the mix.

\section{ACKNOWLEDGMENTS}

The authors thank K. Muthukamarappan for help with viscosity data and Cuirong Ren for assistance with statistical analyses.

\section{REFERENCES}

Alvarez, V. B., C. L. Wolters, Y. Vodovotz, and T. Ji. 2005. Physical properties of ice cream containing milk protein concentrates. J. Dairy Sci. 88:862-871.

AOAC. 2002. Official Methods of Analysis. Vol. II. 17th ed. Association of Official Analytical Chemists, International. Gaithersburg, MD.

Arbuckle, W. S. 1986. Pages 1, 11, 12, 40, 187, 232, and 233 in Ice Cream. 4th ed. AVI Publ. Co., Westport, CT.

Atherton, V. H., and J. A. Newlander. 1977. Pages 105-114, and 142143 in Chemistry and Testing of Dairy Products. 4th ed. AVI Publ. Co., Inc., Westport, CT.

Baer, R. J., and T. P. Czmowski. 1985. Use of the osmometer for quality control of ice cream mix. J. Food Prot. 48:976-978.

Berger, K. G., and G. W. White. 1979. Ice cream. Pages 499-530 in Food Emulsions. S. Friberg, ed. Marcel Dekker, Inc., New York, NY.

Bradley, R., Jr. 1984. Protecting ice cream from heat shock. Dairy Rec. 85(2):120, 122.

Chandan, R. 1997. Pages 30-33 in Dairy-Based Ingredients. Eagen Press, St. Paul, MN.

Dahm, L. 2000. Diamond in the rough. The Cinderella story of whey protein ingredients. Dairy Field 133(20):20.

Donhowe, D. P., R. W. Hartel, and R. L. Bradley, Jr. 1991. Determination of ice crystal size distributions in frozen desserts. J. Dairy Sci. 74:3334-3344.
Dunker, J. M. 1984. The future of whey protein concentrate. Pages 35-39 in Proc. 1984 Whey Products Conf., Chicago, IL. Eastern Regional Research Center, Agricultural Research Service, USDA, Philadelphia, PA.

Flores, A. A., and H. D. Goff. 1999. Ice crystal distributions in dynamically frozen model solutions and ice cream as affected by stabilizers. J. Dairy Sci. 82:1399-1407.

Hagiwara, T., and R. W. Hartel. 1996. Effect of sweetener, stabilizer, and storage temperature on ice recrystallization in ice cream. J. Dairy Sci. 79:735-744.

Hartel, R. W. 1996. Ice crystallization during the manufacture of ice cream. Trends Food Sci. 7:315-321.

Hofi, M., A. Fayed, Z. El-Awamry, and A. Hofi. 1993. Substitution of non fat milk solids in ice cream with ultrafiltration whey protein concentrate. Egypt. J. Food Sci. 21(2):139-145.

Huse, P. A., C. Towler, and W. J. Harper. 1984. Substitution of nonfat milk solids in ice cream with whey protein concentrate and hydrolyzed lactose. N.Z. J. Dairy Sci. Technol. 19:255-261.

Keeney, P. G. 1979. Confusion over heat shock. Food Eng. 51:116-118.

Keeney, P. G., and M. Kroger. 1974. Frozen dairy products. Pages 879-913 in Fundamentals of Dairy Chemistry. 2nd ed. B. H. Webb, A. H. Johnson, and J. A. Alford, ed. AVI Publ. Co., Inc., Westport, CT.

Koxholt, M., T. McIntosh, and B. Eisenmann. 1999. Enhanced stability of ice cream by using particulated whey proteins. Eur. Dairy Magazine 11(1):14-15.

Larmond, E. 1977. Laboratory Methods for Sensory Evaluation of Food. Agric. Can. Publ. No. 1637. Canada Dept. Agric., Ottawa, ON, Canada.

Marshall, R. T., and W. S. Arbuckle. 1996. Pages 59, 151-185, 263267, and 319 in Ice Cream. 5th ed. Int. Thomson Publ., New York, NY.

Marshall, R. T., H. D. Goff, and R. W. Hartel. 2003. Pages 2, 3, 4, 178,289 , and 311 in Ice Cream. 6th ed. Kluwer Academic/ Plenum Publ., New York, NY.

Opdahl, L. J., and R. J. Baer. 1991. Composition and consumer acceptance of frozen yogurt utilizing whey protein concentrates. J. Dairy Sci. 74:4151-4163.

Parsons, J. G., S. T. Dybing, D. S. Coder, K. R. Spurgeon, and S. W. Seas. 1985 . Acceptability of ice cream made with processed wheys and sodium caseinate. J. Dairy Sci. 68:2880-2885.

Ruger, P. R., R. J. Baer, and K. M. Kasperson. 2002. Effect of double homogenization and whey protein concentrate on the texture of ice cream. J. Dairy Sci. 85:1684-1692.

SAS Institute. 1999. SAS User's Guide: Statistics, Version 8.0. SAS Inst., Inc., Cary, NC.

Schmidt, K. 1994. Effect of milk protein and stabilizer on ice milk quality. J. Food Qual. 17:9-19.

Tirumalesha, A., and H. M. Jayaprakasha. 1998. Effect of admixture of spray dried whey protein concentrate and butter milk powder on physico-chemical and sensory characteristics of ice cream. Ind. J. Dairy Sci. 51:13-19.

Turan, S., M. Kirkland, P. A. Trusty, and I. Campbell. 1999. Interaction of fat and air in ice cream. Dairy Ind. Int. 64:27-31.

USDA. 1976. Composition of Foods-Dairy and Egg Products. Agric. Handbook 8-1, Item No. 01-061. USDA, Washington, DC

Walstra, P., and M. Jonkman. 1998. The role of milkfat and protein in ice cream. Pages 17-24 in Ice Cream. W. Buchheim, ed. International Dairy Federation Special Issue 9803. International Dairy Federation, Brussels, Belgium.

Wittinger, S. A., and D. E. Smith. 1986. Effect of sweeteners and stabilizers on selected sensory attributes and shelf life of ice cream. J. Food Sci. 51:1463-1466, 1470. 